ISSN : -

Inovasi Kurikulum, Februari 2004, Thn.1, Vol. 1 Nomor : 1

\title{
PERANAN RINTISAN DALAM PEMBARUAN KURIKULUM
}

\section{Prof. Dr. H. R. IBRAHIM, MA.}

\begin{abstract}
Setiap upaya pembaruan, termasuk pembaruan kurikulum, memerlukan fase rintisan di mana kurikukum baru dilaksanakan dalam skala kecil untuk keperluan pembenahan atau pemantapan sebelum disebarluaskan ke dalam skala yang lebih besar sampai akhirnya diberlakukan secara nasional. Fase rintisan kegiatannya meliputi uji coba dalam hal aspek efektivitas, efisiensi, dan kelaikan/keterlaksanaan. Selain itu, selama fase rintisan, peranan evaluasi juga memiliki peranan yang sangat penting, dan paling tidak, ada tiga jenis evaluasi yang perlu dilakukan selama fase rintisan yaitu evaluasi sumberdaya, evaluasi proses, dan evaluasi hasil. Melalui ketiga jenis evaluasi tersebut, diharapkan dapat diperoleh informasi yang berguna untuk dijadikan masukan bagi pengambilan keputusan tentang pembenahan atau pemantapan program dalam aspek efektivitas, efisiensi, dan kelaikan selama dan pada akhir fase rintisan tersebut
\end{abstract}

Keywords : Rintisan, Uji coba, Evaluasi

\section{Pendahuluan}

Setiap upaya pembaruan, termasuk pembaruan kurikulum, memerlukan fase rintisan di mana kurikukum baru dilaksanakan dalam skala kecil di sejumlah satuan pendidikan untuk keperluan pembenahan atau pemantapan sebelum disebarluaskan ke dalam skala yang lebih besar sampai akhirnya diberlakukan secara nasional. Karena itu lah upaya rintisan ini sering juga disebut ujicoba atau uji lapangan, bahkan ada juga yang menyebutnya pengujian awal. Konsep rintisan atau ujicoba ini berkembang sejalan dengan diterapkannya model pendekatan sistem dalam pengembangan inovasi yang mempersyaratkan ditempuhnya langkahlangkah yang sistematis dalam proses pengembangannya. Upaya pembaruan pendidikan di Indonesia sejak tahun tujuhpuluhan banyak di- 
pengaruhi oleh cara berpikir pen- waktu saja. Pandangan ini medekatan sistem sebagaimana yang nempatkan fase rintisan dalam diterapkan antara lain dalam pem- kedudukan yang sangat penting baruan pendidikan melalui Sekolah (kritikal) sebab mulus tidaknya pePembangunan, SMP Terbuka, Pen- laksanaan upaya pembaruan dalam didikan Terpadu dalam PLB, skala yang lebih besar nanti akan Pendidikan Sistem Ganda pada SMK sangat tergantung dari kegiatan yang sampai dengan Kurikulum Berbasis berhasil kita lakukan selama fase Kompetensi (KBK) pada berbagai rintisan. jenjang pendidikan. Dengan berlatarkan pengaruh model pendekatan sistem, upaya-upaya pembaruan tersebut diawali dengan fase rintisan atau ujicoba dalam skala kecil, dengan harapan bahwa setelah melewati fase ini, pelaksanaan pembaruan dalam skala yang lebih besar nanti akan berjalan dengan relatif mulus.

Isi paparan di atas mengisyaratkan kepada kita bahwa fase rintisan atau ujicoba pada umumnya akan dilanjutkan dengan upaya penyebarluasan pembaruan ke dalam skala yang lebih besar. Ini berarti, pada saat kita telah mencapai fase rintisan, kita sebenarnya telah bertekad menerima pembaruan tersebut untuk nantinya diterapkan dalam sistem pendidikan kita. Oleh sebab itu dalam pendekatan sistem, kegiatan rintisan atau ujicoba diartikan sebagai adopsi awal dari pembaruan yang sedang kita tempuh. Penyebarluasan pembaruan ini ke dalam skala yang lebih besar setelah fase rintisan diasumsikan akan terjadi, hanya soal

\section{Upaya Pembenahan Yang Diperlukan Selama Rintisan}

Agar fase rintisan betul-betul merupakan persiapan ke arah fase pelaksanaan dalam skala yang lebih besar, beberapa pembenahan perlu dilakukan selama fase rintisan tersebut berlangsung. Pembenahan yang dimaksud pada dasarnya berfokus terutama pada aspek efektivitas, efisiensi, dan kelaikan/keterlaksanaan.

Efektivitas:Pembenahan dalam aspek efektivitas diarahkan pada upaya peningkatan ketercapaian tujuan atau kompetensi-kompetensi yang diharapkan melalui pembaruan tersebut. Kita cenderung tidak cepat-cepat menyebarluaskan upaya pembaharuan yang selama rintisan belum memperlihatkan keberhasilannya dalam mencapai tujuan atau kompetensi yang telah ditetapkan.

Efisiensi: Pembenahan dalam aspek efisiensi diarahkan pada upaya peningkatan optimalisasi proses dan 
penggunaan sumberdaya (tenaga, fasilitas, lingkungan, biaya) untuk menghindari terjadinya pemborosan proses dan sumberdaya yang tersedia. Dalam hal ini pun kita tidak ingin menyebarluaskan upaya pembaruan yang selama rintisan berlangsung masih memperlihatkan proses dan pemanfaatan sumberdaya yang kurang optimal sehingga akan menyebabkan terjadinya pemborosan sumberdaya pada satuan-satuan pendidikan yang lain dalam skala yang lebih besar.

Kelaikan/Keterlaksanaan:

Pembenahan dalam aspek kelaikan/ keterlaksanaan diarahkan pada upaya penyesuaian cara-cara yang diempuh dalam melaksanakan pembaruan tersebut agar secara teknis maupun finansial dapat diterapkan oleh satuan-satuan pendidikan lain dalam skala yang lebih besar. Dalam hal-hal tertentu aspek kelaikan ini ada pula sangkut pautnya dengan aspek efisiensi yang telah dipaparkan. Berkenaan dengan aspek yang ketiga ini, kita pun cenderung untuk tidak cepat-cepat menyebarluaskan upaya pembaruan yang dalam fase rintisan pun masih sulit dilaksanakan, tanpa terlebih dahulu mengadakan beberapa penyesuaian/penyederhanaan yang diperlukan dalam teknis pelaksanaannya dengan tetap berpegang pada gagasan pokok semula yang telah disepakati bersama.

\section{Kegiatan Evaluasi yang Perlu Dilakukan}

Untuk dapat melakukan pembenahan dan pemantapan upaya pembaruan selama fase rintisan, peranan evaluasi menjadi sangat penting untuk mendukung (bukan mengancam) keberlangsungan upaya pembaruan tersebut. Dalam hubungan ini, paling tidak, ada tiga jenis evaluasi yang perlu dilakukan selama fase rintisan-evaluasi sumberdaya, evaluasi proses, dan evaluasi hasil.

Evaluasi Sumberdaya, dimaksudkan untuk mengidentifikasikan kesenjangan antara program dan sumberdaya yang diperlukan dengan program dan sumberdaya yang tersedia. Dengan kata lain, melalui evaluasi ini ingin dikaji seberapa jauh program dan sumber daya yang tersedia mendukung pencapaian tujuan dan kompetensi yang diharapkan serta faktorfaktor yang mempengaruhinya.

Evaluasi Proses, dimaksudkan untuk mengidentifikasikan kesenjangan antara proses (pelaksanaan maupun pengelolaan) yang seharusnya ditempuh dan proses yang telah ditempuh dalam melaksanakan upaya pembaruan yang dimaksud. Melalui evaluasi proses ingin dikaji seberapa jauh proses yang berlangsung mendukung pencapaian tujuan dan kompetensi yang diharapkan serta faktor-faktor yang mempengaruhinya. 
Evaluasi Hasil, dimaksudkan untuk mengidentifikasikan kesenjangan antara tujuan dan kompetensi yang diharapkan dengan hasil yang telah dicapai. Melalui evaluasi hasil ingin dikaji seberapa jauh tujuan dan kompetensi yang diharapkan telah berhasil dicapai melalui upaya yang ditempuh selama rintisan berlangsung, serta faktor-faktor yang mempengaruhinya.

Melalui ketiga jenis evaluasi tersebut, diharapkan dapat diperoleh informasi yang berguna untuk dijadikan masukan bagi pengambilan keputusan tentang pembenahan atau pemantapan program dalam aspek efektivitas, efisiensi, dan kelaikan selama dan pada akhir fase rintisan, sebelum pembaruan yang dimaksud disebarluaskan secara bertahap ke dalam skala yang lebih besar.

\section{Penutup}

Pada bagian akhir tulisan singkat ini ingin disimpulkan beberapa hal berkenaan dengan peranan rintisan dalam upaya pembaruan kurikulum sebagai berikut: Pertama, kegiatan rintisan pada dasarnya merupakan fase di mana gagasan-gagasan baru yang terkandung dalam upaya pembaruan diujicobakan dalam skala kecil dengan maksud untuk keperluan pembenahan atau pemantapan, agar upaya penyebarluasannya ke dalam skala yang lebih besar dapat berlangsung secara mulus.

Kedua, lingkup pembenahan atau pemantapan yang perlu dilakukan selama fase rintisan mencakup pembenahan atau pemantapan dalam rangka peningkatan efektivitas, efisiensi dan kelaikan pelaksanaan kurikulum, sebagai persiapan bagi penyebarluasannya ke dalam skala yang lebih besar.

Ketiga, untuk melakukan pembenahan dalam ketiga aspek tersebut diperlukan informasi yang relevan dan berguna yang diperoleh melalui kegiatan evaluasi yang mencakup evaluasi sumberdaya, evaluasi proses, dan evaluasi hasil.

Bertolak dari ketiga simpulan di atas, akhirnya dapat diungkapkan beberapa pelajaran yang dapat dipetik dari paparan tentang peranan rintisan dalam pembaruan kurikulum yaitu (1) kegiatan rintisan dalam skala kecil akan kurang bermanfaat bila tidak disertai pembenahan atau pemantapan program yang pada gilirannya nanti akan disebarluaskan ke dalam skala yang lebih besar; (2) pembenahan atau pemantapan program yang sedang diujicobakan akan kurang terarah bila tidak didukung oleh informasi yang relevan dan berguna yang diperoleh melalui kegiatan evaluasi yang cukup komprehensif; dan (3) kegiatan evaluasi 
yang dilakukan dengan susah payah belum tentu akan bermanfaat bagi upaya pembenahan atau pemantapan yang diinginkan jika hasil (evaluasi) nya tidak ditindaklanjuti dengan tepat dan seksama.

\section{DAFTAR PUSTAKA}

Borg, W.R. \& Gall, M.D., (1979). Educational Research. London: Longman
Lehmann, H. (1990). The Systems Approach to Education. Manila: Innotech Publications

Pusat Kurikulum. (2002). Framework Kurikulum dan Hasil Belajar. Jakarta

Stufflebeam D.L. et al. (1977). Educational Evaluation and Decision Making. Itasca, Illinois: F.E. Feacock Publishers, Inc.

Oliva, P.F., (1992). Developing the Curriculum. New York: Harper Collins Publishers 